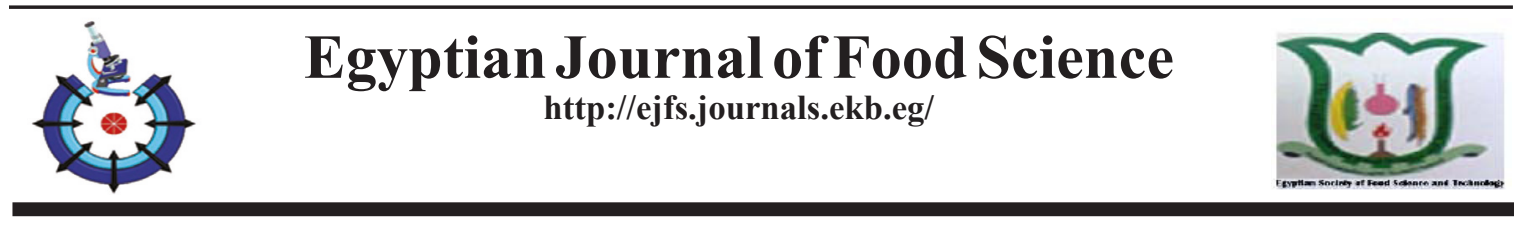

\title{
Quality Characteristics of Sweet Whey-based Fruits Beverages Fermented with Lactobacillus plantarum
}

Esmat Aly*, Aliaa Ali Darwish and Meranda Tawfek

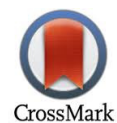

Dairy Technology Research Department, Food Technology Research Institute,

Agricultural Research Center, Giza, Egypt

$\mathbf{T}$

HE current research aimed at developing different beverages through exploitation of sweet whey and incorporation of different proportions of cactus pear juice (10, 20 and $30 \%$, named C10, C20 and C30) and kaki juice (10 and $20 \%$, named K10 and K20). Quality attributes, probiotic viability, and beverages acceptability over 20 days were studied. The obtained findings indicated that fruit juices incorporation increased total solids, total soluble solids, and fiber content. Also, no significant changes $(\mathrm{P}<0.05)$ in the viable numbers of $L$. plantarum due to the change in the concentration or type of the added fruit juices or during cold storage. However, higher viable numbers ranged between 7.59 and $7.89 \log \mathrm{CFU} / \mathrm{mL}$ were obtained. Furthermore, acidity values gradually increased and pronounced changes were observed at 10 days. Total phenolic content (TPC) and antioxidant activity (AOA) significantly increased $(\mathrm{P}<0.05)$ by increasing the added fruit concentrations. K20 treatment had the highest values of TPC (50.68 mg GAE/100 ml), AOA (44.64\%), viscosity (63.86) and WHC (20.67). $\mathrm{C} 30$ treatment obtained the highest score of sensory evaluation. Thus, it could be concluded that cactus pear and kaki juices improved the quality characteristics of whey beverages.

Keywords: Whey-based fruit fermented beverages, Cactus pear and kaki juices, Quality characteristics.

\section{Introduction}

A huge amount of whey is produced worldwide during the cheese industry. Whey is the main byproduct of the dairy industry and it is well-known for its great nutritional value and health-promoting activities (Chavan et al., 2015). Sweet whey is the main byproduct of cheese manufacturing by enzymatic coagulation. It contains half of the total milk solids, all lactose and $20 \%$ of the protein. It is a good source of minerals and vitamins, mainly riboflavin. In addition, some valuable proteins including lactoferrin, $\alpha$-lactalbumin, $\beta$-lactoglobulin, and immunoglobulin are present in sweet whey (Ha and Zemel, 2003). Unfortunately, these valuable nutrients are lost as a result of whey disposal that causes, additionally, serious environmental problems (Smithers et al., 1996). However, whey may be used for processing of several types of powders, protein isolates, riboflavin, lactic acid, and whey cheese...etc (Božanić et al., 2014). Recently, the current trend is the exploitation of whey in the manufacturing of whey beverages. It could be easily incorporated, due to its liquid form, into beverages through mixing with different fruits juices including guava, mango, and orange.... etc. (Gad et al., 2013, Yonis et al., 2014, Chavan et al., 2015). However, other fruits like cactus pear and kaki, despite its nutritional importance, are not used until now in preparation of such beverages.

Cactus pear (opuntia ficus-indica),belonging to the Cactaceae family, is native to Mexico and was subsequently brought to Europe, Africa and the Middle East (Arba, 2006). Its edible fruits are flavored and sweaty (Enigbokan et al., 1996) due to its high sugar content (Stintzing et al., 2003) and low acidity (Muñoz de Chávez et al., 1995). In addition, these fruits are considered a good source of vitamins and minerals including $\mathrm{Ca}$, $\mathrm{Mg}, \mathrm{K}$ and $\mathrm{P}$ (Feugang et al., 2006). Moreover,

"Corresponding author : esmat_rayan_2010@yahoo.com

Received:07/10/2019; accepted:23/12/2019

DOI: 10.21608/EJFS.2019.17601.1024

(C2019 National Information and Documentation Centre (NIDOC) 
several bioactive antioxidant compounds are found in these fruits such as betalains, ascorbic acid, and polyphenols (Magloire et al., 2006). Recently, Baccouche et al. (2013) developed acid whey-based cactus pear beverages.

Regarding the fleshy fibrous kaki fruit (Diospyros kaki), it belongs to Ebeneceae family (Luo \& Wang, 2008). It has high nutritional and therapeutic benefits including antioxidant, anticancer (Suzuki et al., 2005), and hypolipidemic effects (Park et al., 2008) because it has a high amount of water-soluble dietary fiber, ascorbic acid, polyphenols, carotenoids and minerals (Suzuki et al., 2005). Cactus pear and kaki fruits share a similarity regarding its consumption in only fresh form and are not used for juices production at an industrial level in Egypt. Thus, mixing these fruits pulp with sweet whey in the presence of suitable stabilizer represents another aspect to exploit these three under-utilized food materials.

In recent times, significantly large numbers of consumers seek health promoting functional foods, including low energy beverages that are sweetened by natural sweeteners, e.g. stevia (Jeličić et al., 2008). The value of these beverages and their demand is increasing as a result of its fermentation, especially with probiotic bacteria. Thus, several functional whey-based fermented beverages using several strains of probiotic bacteria were developed (Almeida et al, 2008) including L. acidophilus and B. animalis Bb-12 (Castro et al., 2013), L. rhamnosus ATCC 7469 (Bulatović et al., 2014), L. acidophilus, B. animalis subsp. lactis and Streptococcus thermophilus (Akpinar et al., 2015), and L. rhamnosus GG \& B. animalis ssp. lactis Bb-12 (AbdulAlim et al., 2018). Among these probiotic cultures, the strain named L. plantarum is known for its health benefits including antidiabetic, anticancer and antioxidant properties.

Thus and in view of the above-mentioned, the worldwide beverages markets offer a wide range of whey-based liquid products which may be include fermented or nonfermented beverages, whey-fruit or vegetable juice mixture, probiotic/ prebiotic/symbiotic whey beverages, enriched or supplemented whey beverages so on (Turkmen, et al., 2019). In the same context, the current study was devoted to develop and evaluate the quality attributes, beverages acceptability and shelf life of novel whey-based fruit beverages fermented with L. plantarum incorporated with fruit juices of cactus pear or kaki fruits.

Egypt. J. Food. 47, No.2 (2019)

\section{Materials and Methods}

Chemicals and probiotic strain

Carboxymethylecellulose (CMC) was obtained from Misr Food Additives (MIFAD). Stevia powder (200 times as sweet as sucrose) was purchased from L.M.G. international trade corporation, Egypt. The pure probiotic culture of L. plantarum strain was obtained from Chr. Hansen, (Copenhagen, Denmark).

Sweet whey, cactus pear and kaki fruits

Fresh sweet whey was obtained from the Dairy Technology Unit, Faculty of Agriculture, Cairo University. The sweet whey was obtained as a by-product of Ras cheese manufacturing and used throughout the current research as a base to formulate the different blends of beverages. Fresh fully ripened cactus pear (Opuntia ficus-indica L.) and kaki (Diospyros kaki L.) fruits were purchased from alocal market at Giza city, Egypt. These two fruits were washed thoroughly to remove the dirt, peeled and cut into small pieces. Then, the pieces of each fruit were mixed in a kitchen blender and filtered through a cheese-cloth to remove the seeds. The obtained pulpy juices were then filled into polyethylene bags and stored at $-18^{\circ} \mathrm{C}$ until use.

\section{Beverages preparation}

Whey-based fruit beverages were prepared by blending of sweet whey and cactus pear or kaki juices in different proportions ranged between 10 $50 \%$. The various proportion of fruit juices (cactus pear or kaki) and sweet whey along with $0.05 \%$ $(\mathrm{w} / \mathrm{v})$ stevia, and $0.20 \%(\mathrm{w} / \mathrm{v}) \mathrm{CMC}$ were used for the preparation of sweet whey-based fruit beverages. The proportion of stevia and CMC were maintained constant in all the formulations and were dissolved in the blends. All blends were well mixed, thermally treated to $75^{\circ} \mathrm{C}$ for $30 \mathrm{~min}$ and rapidly cooled to 38 $\pm 1^{\circ} \mathrm{C}$. Then, they were inoculated with a probiotic culture of L.plantarum (3\%) in order to provide the minimum number of live microbes that met the regulatory requirements. Therefter, the blends were incubated at $38 \pm 1^{\circ} \mathrm{C}$ for $3 \mathrm{hr}$. Thus, the prepared beverages were aseptically filled in previously sterilized glass bottles $(100 \mathrm{ml})$ leaving $2.5 \mathrm{~cm}$ headspace and sealed airtight by crown corking. The various beverages were stored at $4^{\circ} \mathrm{C}$ for 20 days storage studies and subjected to chemical, microbiological and organoleptic analyses at a regular interval of 5 days except the determination of total phenolic content (TPC), antioxidant activity (AOA \%) and sensory evaluation which have sampling points of each 10 days. All analyses were carried out in triplicate. 


\section{Preliminary sensory evaluation study}

In the current research, a preliminary study was conducted to select the best blends of sweet whey with cactus pear or kaki fruit juices. Five blends of sweet whey with cactus pear juice and another five blends of sweet whey with kaki fruit juice were developed. The proportions used of the fruit juices were ranged between 10-50 $\%$. These ten different blends were subjected to sensory evaluation by a panel of trained experts. Table 1 summarizes the various formulations of whey-based fruit beverages fermented with $L$. plantarum tested in this experiment. Preliminary sensory evaluation study conducted on these beverages showed that only 3 blends with cactus pear juice (10, 20 and $30 \%)$ and two blends with kaki juice (10 and $20 \%$ ) were acceptable. Hence, only these combinations were tested in the current study. The acceptable blends were:

$\mathrm{C} 10=$ Sweet whey and cactus pear juice (90: 10)

$\mathrm{C} 20=$ Sweet whey and cactus pear juice $(80: 20)$

$\mathrm{C} 30=$ Sweet whey and cactus pear juice (70: 30)

$\mathrm{K} 10=$ Sweet whey and kaki juice (90: 10)

K20 = Sweet whey and kaki juice (80: 20)

\section{Analytical methods}

Chemical composition

The chemical composition of sweet whey, cactus pear, kaki juices, and the prepared beverages was determined in triplicate. Total solids, fat, protein, ash, and fiber content were determined according to AOAC (2007). The $\mathrm{pH}$ values of various samples were measured by $\mathrm{pH}$ meter (Hanna, digital pH meter, Spain) while titratable acidity (as lactic acid \%) was determined according to Dilmi-Bouras (2006). Total soluble solids (TSS) content (as Brix) was measured at $20 \mathrm{C}$ by refractometer (Abbe Hergestellt in der DDR, Germany).

\section{Viable counts of L. plantarum}

Regarding the viability of probiotic strain used in this study, the various beverages were checked for its viable numbers of L. plantarum using MRS media (Biolife Italiana, Milano, Italy) according to Mantzourani et al. (2019).

\section{Total phenolic content and antioxidant activity}

Total phenolic content (TPC) was determined using Folin-Ciocalteu reagent (Sigma-Aldrich, Steinhein, Germany) according to Abirami et al.(2014) and modified by Yang et al. (2018). Gallic acid (Sigma-Aldrich, Steinhein, Germany) was used as standard and the results expressed as $\mathrm{mg}$ gallic acid equivalent/100 $\mathrm{ml}(\mathrm{mg}$ GAE/100 ml). While the antioxidant activity (AOA \%) was measured by determination of DPPH-radical scavenging activity according to Brand-Williams et al. (1995).

\section{Viscosity and water holding capacity (WHC)}

Viscosity was determined according to Vercet et al. (2002) while WHC (\%) was measured as described by Guzman-Gonzalez et al. (1999).

\section{Sensory evaluation}

Sensory acceptability was assessed for the various whey-based fruit beverages fermented with L. plantarum. It was conducted using 10 panel trained experts belonging to Food Technology Research Institute members. Each participant is asked to indicate acceptability and to identify the descriptor (color and appearance, texture, flavor, and overall acceptability) that contributed to their answer.

\section{Statistical analysis}

Statistical analysis of the data was carried out by ANOVA using M-stat statistical software. The value of each treatment was expressed as the average of three replicates \pm standard deviation. The significant differences among means were assessed by t-test.

\section{Results and Discussion}

Chemical composition of sweet whey and fruit juices

The chemical composition of sweet whey, cactus pear and kaki fruit juices present in Table 2 . The obtained results indicated that sweet whey has $\mathrm{pH}$ value of 5.56 and contains $6.4 \%$ total solids, $5.7 \%$ total soluble solids, $0.20 \%$ fat, $0.9 \%$ protein, $4.80 \%$ lactose, and $0.50 \%$ ash. The current results are in general agreement with those reported by Ragab et al. (2010), and Yonis et al. (2014). As shown in Table 2, cactus pear fruit juice contains $17.31 \%$ total solids, $10.50 \%$ total soluble solids, $0.50 \%$ fat, $0.96 \%$ protein, and $0.65 \%$ ash while kaki juice contains $22.85 \%$ total solids, $14.10 \%$ total soluble solids, $0.18 \%$ fat, $0.57 \%$ protein, $18.16 \%$ and $0.34 \%$ ash. The results also displayed that cactus pear and kaki juices have $3.86 \%$ and $3.60 \%$ of total fiber, respectively. Thus, kaki juice had a higher content of total solids $(22.85 \%)$, and total soluble solids (14.10\%) than cactus pear juice. The data obtained by Yaqub et al. (2016) regarding the chemical composition of kaki juice are in line with our obtained data. 
TABLE. 1. The various formulations of whey-based fruit beverages and the given codes of the accepted formulations*

\begin{tabular}{|c|c|c|c|c|}
\hline Blends & Sweet whey & Cactus pear juice & Kaki juice & $\begin{array}{l}\text { Codes of accepted } \\
\text { formulations }\end{array}$ \\
\hline 1 & 90 & 10 & - & $\mathrm{C} 10$ \\
\hline 2 & 80 & 20 & - & $\mathrm{C} 20$ \\
\hline 3 & 70 & 30 & - & $\mathrm{C} 30$ \\
\hline 4 & 60 & 40 & - & - \\
\hline 5 & 50 & 50 & - & - \\
\hline 6 & 90 & - & 10 & K10 \\
\hline 7 & 80 & - & 20 & $\mathrm{~K} 20$ \\
\hline 8 & 70 & - & 30 & - \\
\hline 9 & 60 & - & 40 & - \\
\hline 10 & 50 & - & 50 & - \\
\hline
\end{tabular}

* Each formulation contains a constant amount of stevia $(0.05 \%, \mathrm{w} / \mathrm{v})$ and carboxymethylecellulose (CMC, $0.20 \%, \mathrm{w} / \mathrm{v})$.

TABLE 2. The chemical composition of sweet whey, cactus pear, and kaki fruit juices.

\begin{tabular}{|l|c|c|c|}
\hline Parameter & Sweet whey & Cactus pear & Kaki \\
\hline Total solids (\%) & $6.40 \pm 0.46$ & $17.31 \pm 1.85$ & $22.85 \pm 4.19$ \\
\hline Total soluble solids (\%) & $5.70 \pm 0.63$ & $10.5 \pm 0.49$ & $14.1 \pm 2.38$ \\
\hline Fat (\%) & $0.20 \pm 0.01$ & $0.50 \pm 0.21$ & $0.18 \pm 0.001$ \\
\hline Protein (\%) & $0.90 \pm 0.10$ & $0.96 \pm 0.02$ & $0.57 \pm 0.13$ \\
\hline Ash (\%) & $0.50 \pm 0.08$ & $0.65 \pm 0.04$ & $0.34 \pm 0.07$ \\
\hline Fiber (\%) & $\mathrm{ND}$ & $3.86 \pm 0.46$ & $3.60 \pm 0.77$ \\
\hline pH & $5.56 \pm 0.10$ & $6.30 \pm 0.25$ & $5.28 \pm 0.47$ \\
\hline Total phenolic content (mg GAE/ 100 ml) & $\mathrm{ND}$ & $156.06 \pm 5.98$ & $235.67 \pm 8.97$ \\
\hline Antioxidant activity (\%) & $5.89 \pm 0.51$ & $66.15 \pm 3.96$ & $79.85 \pm 5.95$ \\
\hline
\end{tabular}

Egypt. J. Food. 47, No.2 (2019) 
Regarding TPC and AOA, kaki juices had the highest value of TPC (235.67 mg GAE/100 ml) and AOA (79.85\%) and the lowest values were recorded for cactus pear juice. Nazir et al. (2013) revealed that kaki pulp extract had high radical scavenging activity $(67 \%)$. The high antioxidant activity of food of plant origin can be attributed to their flavonoid, ascorbic acid, and carotenoid contents (Albano et al., 2015). Generally, the chemical composition of the edible part of the fruit varies depending on several factors including species, area of cultivation, environmental conditions and ripening stage (FAO, 2013).

Proximate composition of whey-based fruit beverages

Table 3 showed the chemical composition of whey-based fruit beverages fermented with L. plantarum. Significant changes $(\mathrm{P}<0.05)$ were observed in the values of total solids, total soluble solids, and fiber content by fruit juices incorporation. However, insignificant changes were observed for protein and ash content despite its increment. It was found that C30 treatment had a higher content of total solids $(11.45 \%)$, TSS $(8.28 \%)$, total protein $(1.10 \%)$, ash $(0.52 \%)$ and fiber $(4.62 \%)$ as can be seen in Table 3. Bhavsagar et al. (2010) observed that the increasing added level of fruit juices to whey results in increased protein, ash and total solid content of the resultant products. A similar observation was reported by Nairu et al. (2011) when orange pulp was added to whey. Recently, Prashanth et al. (2018) revealed that total solid, protein and ash contents of whey beverages increased with the increasing of fruit incorporated. Therefore, incorporation of fruits in whey beverages could represent a good way to produce products with high nutritional value.

\section{Viability of L. plantarum}

Another noticeable change occurred by fruit addition is associated with the microbiological properties of the tested beverages. As can be seen in Table 4 , the viable counts of $L$. plantarum positively influenced by fruit juices addition. The initial counts of $L$. plantarum were above $7 \log \mathrm{CFU} / \mathrm{ml}$ in all treatments and $\mathrm{C} 10$ has the lowest viable number at first day of cold storage time. Generally, the addition of fruit juices caused a noticeable increase $(\mathrm{P}<0.05)$ in the viable numbers of this probiotic strain of all treatments especially at 10 and 15 days but its viable counts declined at 20 days of cold storage time. This probiotic culture exhibited high viability during the storage time of these beverages with viable numbers ranged between 7.59 and $7.89 \log \mathrm{CFU} / \mathrm{mL}$ (final storage time). Interestingly, as shown in Table 4 , there were no significant changes $(\mathrm{P}<0.05)$ in the viable number of $L$. plantarum due to the change in the concentration or type of added fruit juices over 20 days of cold storage time. However, it 's worth noting that addition of kaki juice led to higher viable counts in treatments K10 and $\mathrm{K} 20$ as compared to that contain a similar proportion of cactus pear juice at the same corresponding time of cold storage.

TABLE 3. The chemical composition of whey-based fruit beverages fermented with Lactobacillus plantarum.

\begin{tabular}{|l|c|c|c|c|c|}
\hline Parameters & $\mathbf{C 1 0}$ & $\mathbf{C 2 0}$ & $\mathbf{C 3 0}$ & $\mathbf{K 1 0}$ & K20 \\
\hline Total solids (\%) & $7.99 \pm 1.23^{\mathrm{B}}$ & $9.72 \pm 2.33^{\mathrm{AB}}$ & $11.45 \pm 3.11^{\mathrm{A}}$ & $8.54 \pm 1.44^{\mathrm{AB}}$ & $10.83 \pm 2.23^{\mathrm{BC}}$ \\
\hline $\begin{array}{l}\text { Total soluble } \\
\text { solids (\%) }\end{array}$ & $6.18 \pm 1.69^{\mathrm{A}}$ & $7.23 \pm 1.45^{\mathrm{A}}$ & $8.28 \pm 0.46^{\mathrm{A}}$ & $6.54 \pm 2.06^{\mathrm{AB}}$ & $7.95 \pm 1.32^{\mathrm{BC}}$ \\
\hline Protein (\%) & $0.91 \pm 0.23^{\mathrm{A}}$ & $1.01 \pm 0.02^{\mathrm{A}}$ & $1.10 \pm 0.03^{\mathrm{A}}$ & $0.87 \pm 0.28^{\mathrm{A}}$ & $0.92 \pm 0.34^{\mathrm{A}}$ \\
\hline Ash (\%) & $0.52 \pm 0.08^{\mathrm{A}}$ & $0.58 \pm 0.16^{\mathrm{A}}$ & $0.65 \pm 0.04^{\mathrm{A}}$ & $0.48 \pm 0.06^{\mathrm{A}}$ & $0.52 \pm 0.05^{\mathrm{A}}$ \\
\hline Fiber (\%) & $3.85 \pm 0.43^{\mathrm{A}}$ & $4.24 \pm 0.64^{\mathrm{B}}$ & $4.62 \pm 1.13^{\mathrm{C}}$ & $3.83 \pm 0.83^{\mathrm{A}}$ & $4.19 \pm 0.86^{\mathrm{B}}$ \\
\hline
\end{tabular}

Values are means $\pm \mathrm{SD}$ of three independent experiments. Means with different superscripts $(\mathrm{A}, \mathrm{B} \ldots$... in each row for each type of added fruit for the various parameters are significantly different $(\mathrm{P}<0.05)$. C10, C20, C30: whey-based fruit beverages fermented with $L$. plantarum containing 10, 20,30 \% cactus pear juice, respectively. K10 and K20: whey-based fruit beverages fermented with L. plantarum containing 10 and $20 \%$ kaki juice, respectively. 
TABLE 4. Viable cell counts (log CFU/ml) of whey-based fruit beverages fermented with Lactobacillus plantarum during cold storage time at $5{ }^{\circ} \mathrm{C}$.

\begin{tabular}{|c|c|c|c|c|c|}
\hline \multirow{2}{*}{$\begin{array}{c}\text { Storage } \\
\text { time } \\
(\text { days }\end{array}$} & \multicolumn{5}{|c|}{ Viable counts of L. plantarum (log CFU/ml) } \\
\cline { 2 - 6 } & $\mathbf{C 1 0}$ & $\mathbf{C 2 0}$ & $\mathbf{C 3 0}$ & $\mathbf{K 1 0}$ & \multirow{2}{*}{$\mathbf{K 2 0}^{-5}$} \\
\hline $\mathbf{1}$ & $7.32 \pm 1.23^{\mathrm{aA}}$ & $7.45 \pm 1.07^{\mathrm{aA}}$ & $7.50 \pm 1.30^{\mathrm{aA}}$ & $7.46 \pm 0.86^{\mathrm{aA}}$ & $7.48 \pm 0.84^{\mathrm{aA}}$ \\
\hline $\mathbf{5}$ & $7.50 \pm 2.06^{\mathrm{aA}}$ & $7.77 \pm 2.53^{\mathrm{aA}}$ & $7.80 \pm 1.07^{\mathrm{aA}}$ & $7.75 \pm 0.96^{\mathrm{aA}}$ & $7.78 \pm 2.16^{\mathrm{aA}}$ \\
\hline $\mathbf{1 0}$ & $8.10 \pm 1.64^{\mathrm{aA}}$ & $8.12 \pm 0.89^{\mathrm{aA}}$ & $8.22 \pm 2.61^{\mathrm{aA}}$ & $8.15 \pm 1.55^{\mathrm{aA}}$ & $8.25 \pm 2.03^{\mathrm{aA}}$ \\
\hline $\mathbf{1 5}$ & $7.83 \pm 1.46^{\mathrm{aA}}$ & $8.01 \pm 1.96^{\mathrm{aA}}$ & $8.101 .18^{\mathrm{aA}}$ & $7.96 \pm 1.65^{\mathrm{aA}}$ & $8.03 \pm 1.37^{\mathrm{aA}}$ \\
\hline $\mathbf{2 0}$ & $7.59 \pm 1.76^{\mathrm{aA}}$ & $7.85 \pm 2.33^{\mathrm{aA}}$ & $7.89 \pm 1.29^{\mathrm{aA}}$ & $7.87 \pm 1.07^{\mathrm{aA}}$ & $7.89 \pm 1.76^{\mathrm{aA}}$ \\
\hline
\end{tabular}

Values are means \pm SD of three independent experiments. Means with different superscripts (A, B...) in each row for each type of fruit added at the same time for the various treatments are significantly different $(\mathrm{P}<0.05)$ while means with different superscripts $(\mathrm{a}, \mathrm{b} \ldots)$ in each column at various storage time for each treatment are significantly different $(\mathrm{P}<$ 0.05). CFU: colony-forming unit. C10, C20, C30: whey-based fruit beverages fermented with L. plantarum containing 10, 20, $30 \%$ cactus pear juice, respectively. K10 and K20: whey-based fruit beverages fermented with L. plantarum containing 10 and $20 \%$ kaki juice, respectively.

Moreover, the total viable numbers obtained in the current study were in the range of 7.32 - $8.25 \log \mathrm{CFU} / \mathrm{mL}$ as reported for yoghurt (Keating \& White, 1990), and probiotic dairy beverages (Darwish et al., 2018). Thus, the various beverages contain higher viable numbers of probiotic than the minimal amount of $10^{6} \mathrm{CFU} / \mathrm{g}$ or $\mathrm{ml}$ that compensate the cell loss resulted by the gastrointestinal tract conditions and thus providing the potential health benefits to the host (Vandenplas et al. 2015). Probiotic bacteria survivability in whey beverages containing food of plant origins such as fruits, vegetables or even its waste might be influenced by its composition.

In this sense, Capela et al. (2006) revealed that prebiotics significantly improved the survivability of probiotic bacteria in various products. Such components act as fermentable substrates by probiotics participating in improving its growth and viability. Furthermore, the presence of prebiotics including dietary fiber may explain the greater stability of such bacteria in whey beverages. Additionally, Lee et al. (2006) indicated that intestinal microflora can metabolize plant polyphenols (such as catechin, epicatechin, and gallic acid) leading to viability enhancement of Lactobacilli spp. In view of this, it is wellknown that cactus pear fruit is an important source of dietary fiber including pectin, mucilage (Sáenz et al., 2013) and sugars such as glucose and fructose (Lee et al., 2012).

Acidity and $\mathrm{pH}$ values

It is well-known that probiotic growth and viability, resulted by fermentation of the carbohydrate present in products, led to increasing the acidity and decreasing $\mathrm{pH}$ values. Fig 1 . showed the titratable acidity and $\mathrm{pH}$ values in the tested beverages. It can be observed that titratable acidity values gradually increased while $\mathrm{pH}$ values gradually decreased during the cold storage time. These changes were pronouncedat 10 and 20 days of cold storage. The acidity values varied between $0.28-0.43 \mathrm{~g}$ lactic acid in $100 \mathrm{ml}$ while $\mathrm{pH}$ values ranged between $4.28-5.40$. These modifications are mainly contributing to the transformation of lactose and other carbohydrates to organic acids mainly lactic acid. Aamer et al. (2017) has noted similar results in beverages containing whey and permeate blended with kumquat fruit. 


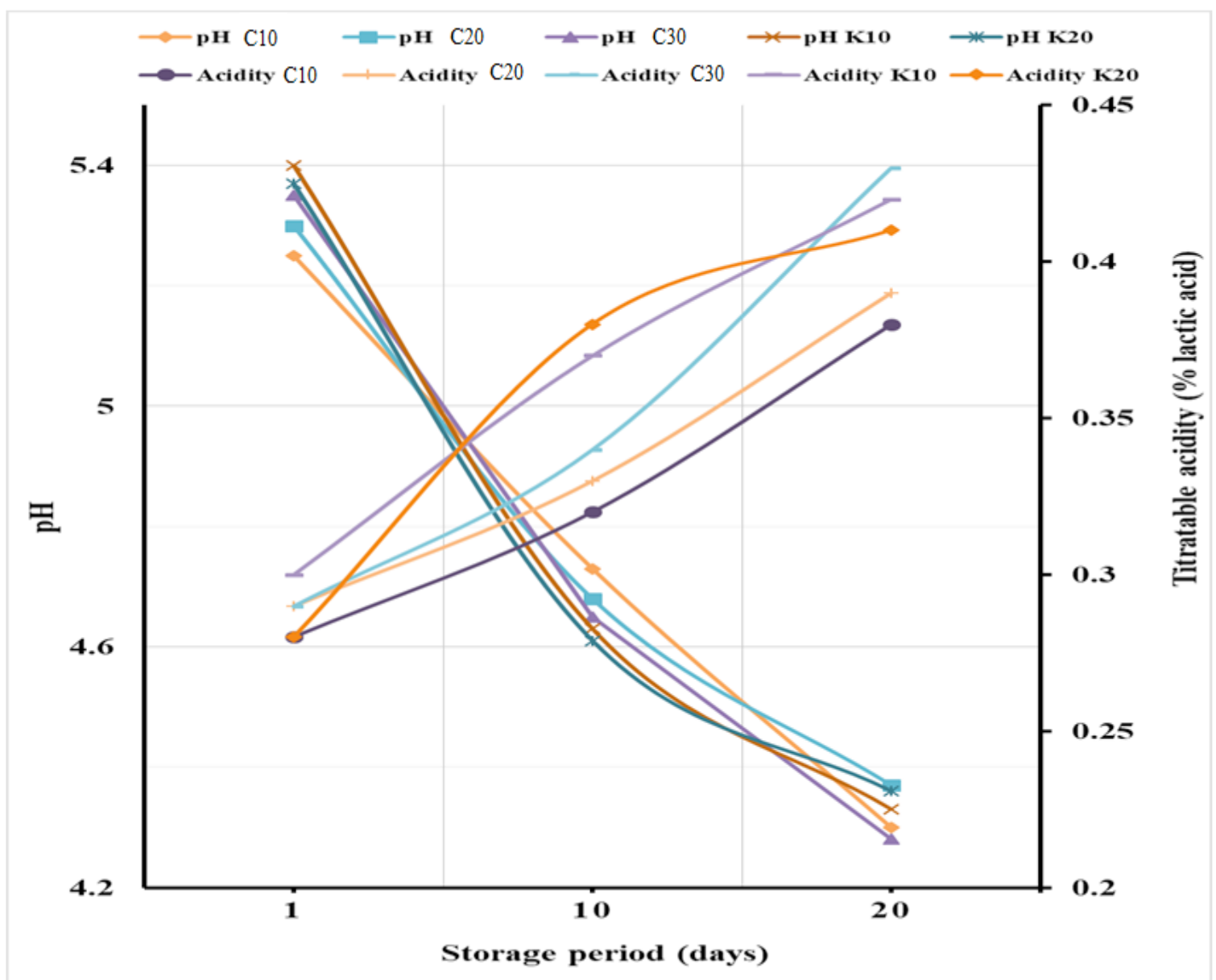

Fig. 1. Titratable acidity and $\mathrm{pH}$ values of whey-based fruit beverages fermented with Lactobacillus plantarum during cold storage time at $5{ }^{\circ} \mathrm{C}$. Values are means $\pm \mathrm{SD}$ of three independent experiments. $\mathrm{C10}, \mathrm{C20}$, C30: whey-based fruit beverages fermented with $L$. plantarum containing $10,20,30 \%$ cactus pear juice, respectively. K10 and K20: whey-based fruit beverages fermented with L. plantarum containing 10 and 20 $\%$ kaki juice, respectively.

Total phenolic content and antioxidant activity

The data present in Table 5 showed the total phenolic content (TPC, mg GAE/100 ml) and the antioxidant activity (\%) of the tested beverages. The higher fruit juices incorporated, the higher $\mathrm{TPC}$ and AOA values reported. Interestingly, there were significant changes $(\mathrm{P}<0.05)$ in TPC and AOA values due to the change in the concentration of added fruit juices. On the other hand, TPC and AOA values increased at 10 days and then declined at 20 days keeping slightly lower values than initial ones. Generally, TPC values ranged between 12.58 - $47.68 \mathrm{mg} \mathrm{GAE} / 100 \mathrm{ml}$ for $\mathrm{C} 10$, $\mathrm{C} 20$, and $\mathrm{C} 30$ beverages while it ranged between 22.71 - $50.68 \mathrm{mg} \mathrm{GAE} / 100 \mathrm{ml}$ for K10 and K20 beverages.

Regarding AOA (\%), the values ranged between $25.60-42.79(\%)$ for C10, C20, and C30 while the range of these values was between 32.31 - 44.64 (\%) for K10 and K20. The beverages containing kaki fruit juices (K20) had the highest values of TPC and AOA \%. Similar results were obtained by Aamer et al. (2017) indicating that TPC and antioxidant activity of whey and permeate containing kumquat fruit gradually decreased at 14 and 28 days of cold storage. Similarly, Sreerupa et al. (2014) obtained similar results that were in general agreement with the current data.Recently, Albano et al. (2015) and Maulidiani et al. (2018) indicated that cactus pear and kaki fruits are well-known for its high content in several antioxidants including vitamin $\mathrm{C}$ and polyphenols. These components may scavenge reactive free radicals and inhibit radical chain reactions or may act as metal chelators preventing the radical formation (Forman, Davies \& Ursini, 2014). 
TABLE 5. Total phenolic content $(\mathrm{mg} \mathrm{GAE} / 100 \mathrm{ml})$ and antioxidant activity $(\%)$ of whey-based fruit beverages fermented with Lactobacillus plantarum during cold storage time at $5^{\circ} \mathrm{C}$.

\begin{tabular}{|c|c|c|c|c|c|}
\hline $\begin{array}{l}\text { Storage time } \\
\text { (days) }\end{array}$ & $\mathrm{C10}$ & $\mathrm{C20}$ & C30 & K10 & K20 \\
\hline \multicolumn{6}{|c|}{ Total phenolic content (mg GAE/100 ml) } \\
\hline 1 & $14.68^{\mathrm{abC}}$ & $29.72^{\mathrm{aB}}$ & $44.08^{\mathrm{abA}}$ & $24.69^{\mathrm{bB}}$ & $47.68^{\mathrm{aA}}$ \\
\hline 10 & $17.36^{\mathrm{aC}}$ & $31.69^{\mathrm{aB}}$ & $47.68^{\mathrm{aA}}$ & $28.46^{\mathrm{aB}}$ & $50.68^{\mathrm{aA}}$ \\
\hline 20 & $12.58^{\mathrm{bC}}$ & $28.56^{\mathrm{aB}}$ & $41.87^{\mathrm{bA}}$ & $22.71^{\mathrm{bB}}$ & $44.28^{\mathrm{bA}}$ \\
\hline \multicolumn{6}{|c|}{ Antioxidant activity (\%) } \\
\hline 1 & $27.38^{\mathrm{bC}}$ & $36.94^{\mathrm{abB}}$ & $40.23^{\mathrm{abA}}$ & 34.64 abB & $40.97^{\mathrm{bA}}$ \\
\hline 10 & $31.68^{\mathrm{aC}}$ & $38.21^{\mathrm{aB}}$ & $42.79^{\mathrm{aA}}$ & $37.48^{\mathrm{aB}}$ & $44.64^{\mathrm{aA}}$ \\
\hline 20 & $25.60^{\mathrm{bC}}$ & $33.64^{\mathrm{bB}}$ & $38.08^{\mathrm{bA}}$ & $32.31^{\mathrm{bB}}$ & $38.16^{\mathrm{bA}}$ \\
\hline
\end{tabular}

Values are means \pm SD of three independent experiments. Means with different superscripts (A, B...) in each row for each type of fruit added at the same time for the various treatments are significantly different $(\mathrm{P}<0.05)$ while means with different superscripts $(\mathrm{a}, \mathrm{b} \ldots)$ in each column at various storage time for each treatment are significantly different $(\mathrm{P}<$ 0.05). GAE: gallic acid equivalent. C10, C20, C30: whey-based fruit beverages fermented with L. plantarum containing 10, 20, $30 \%$ cactus pear juice, respectively. K10 and K20: whey-based fruit beverages fermented with L. plantarum containing 10 and $20 \%$ kaki juice, respectively.

Viscosity and water holding capacity

Besides that, amongst the positive effects of fruit utilization in dairy industry is its ability to improve the physical properties of the products. The obtained results in Fig. 2 and Fig. 3 showed beverages viscosity and WHC values, respectively. Viscosity values ranged between $31.34-63.86 \mathrm{Cp}$ while WHC values ranged between 8.97-20.67\%. The highest values of viscosity and WHC were recorded for K20 followed by K10 (at final storage time) while the lowest values were for C10 followed by C20 (at 1 day of storage time). Generally, viscosity and WHC increased by increasing the incorporation level of fruit juices and with the progress of cold storage time.The increased viscosity and WHC values could be related to the higher contents of fiber present in fruits including pectin and mucilage in cactus pear fruit (Sáenz et al., 2004) and dietary fiber and tannin in kaki fruit (Dalvi et al., 2018). Similarly, this effect can be partially explained by high water binding capacity by added solids (Mahmood et al., 2008) forming a firmer gel and thus inhibits the separation of whey. Thus, a linear relationship between fruit incorporation, total solids, product viscosity, and WHC was reported. Some previously reported data consisted with the current results revealed that higher viscosity was observed in yoghurt incorporated with passion fruit (Espirito-Santo et al., 2013) or kaki and kiwi fruits (Farahat and El-Batawy, 2013) compared to the plain yoghurt. 


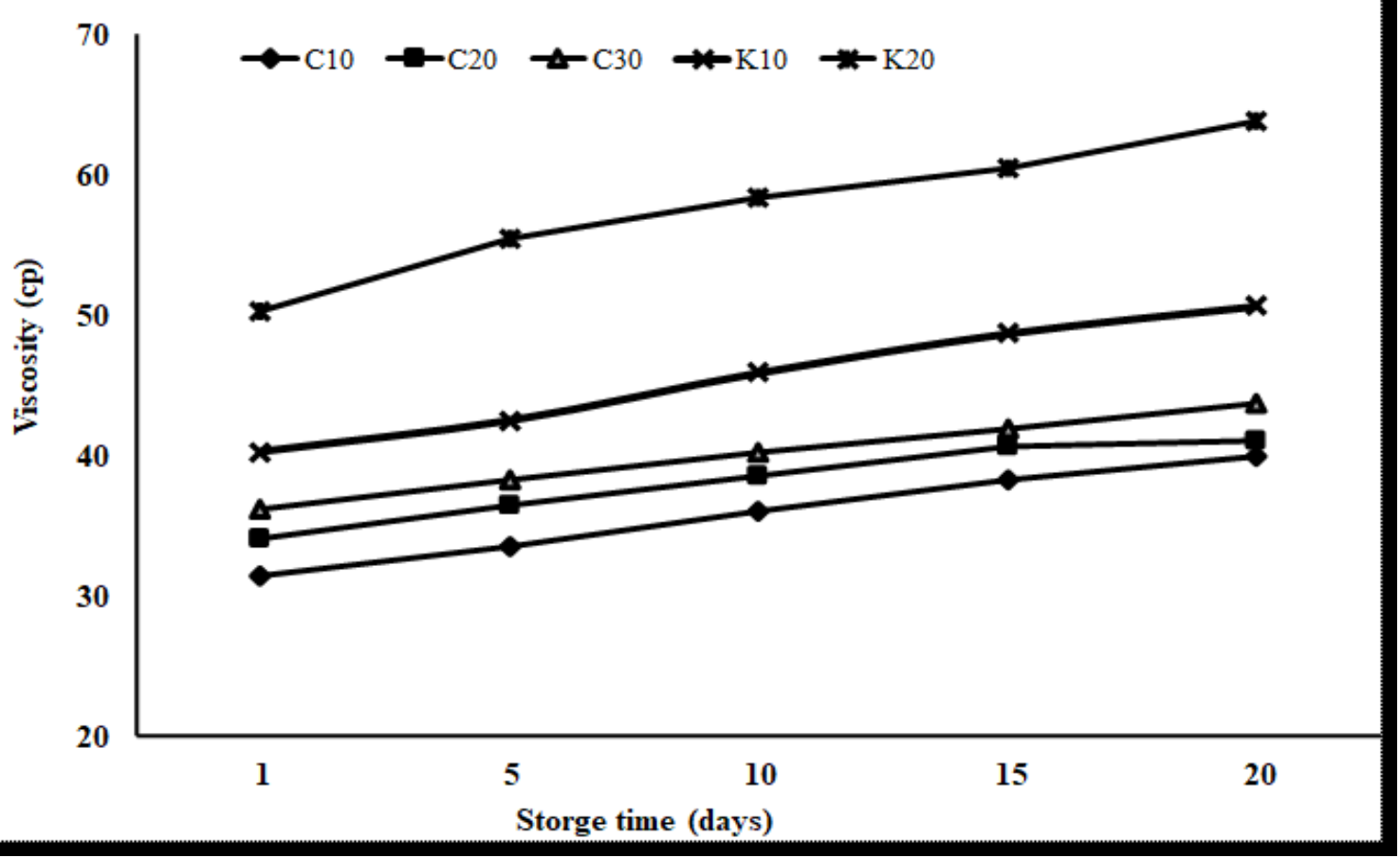

Fig. 2. Viscosity (cp) of whey-based fruit beverages fermented with Lactobacillus plantarum during cold storage time at $5{ }^{\circ} \mathbf{C}$. Values are means \pm SD of three independent experiments. C10, C20, C30: whey-based fruit beverages fermented with $L$. plantarum containing 10, 20, $30 \%$ cactus pear juice, respectively. K10 and K20: whey-based fruit beverages fermented with L. plantarum containing 10 and $20 \%$ kaki juice, respectively.

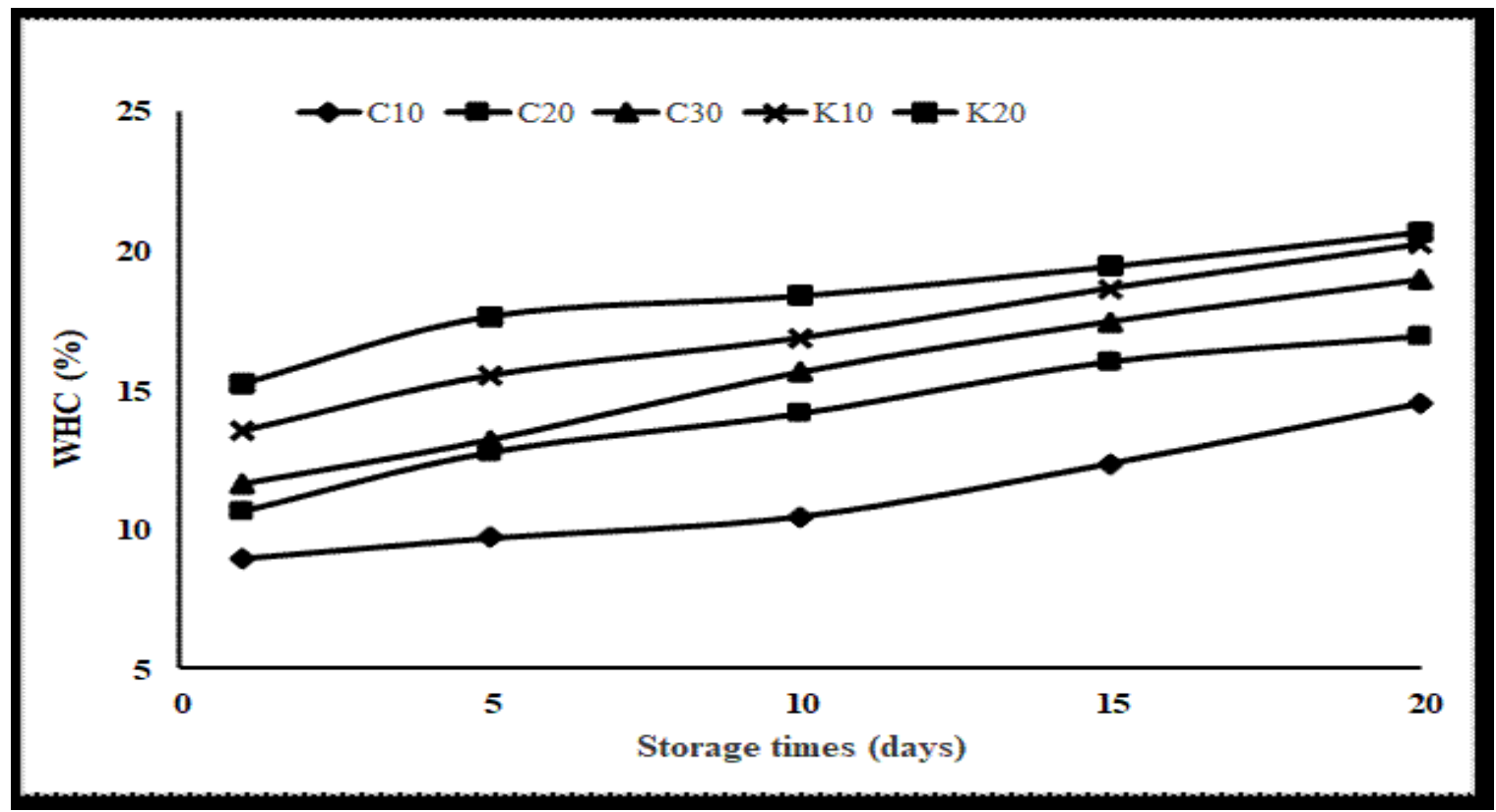

Fig. 3. Water holding capacity (WHC \%) of whey-based fruit beverages fermented with Lactobacillus plantarum during cold storage time at $5^{\circ} \mathbf{C}$. Values are means \pm SD of three independent experiments. C10, C20, C30: whey-based fruit beverages fermented with $L$. plantarum containing 10, 20, $30 \%$ cactus pear juice, respectively. $\mathrm{K} 10$ and K20: whey-based fruit beverages fermented with $L$. plantarum containing 10 and $20 \%$ kaki juice, respectively. 


\section{Sensory attributes}

The changes in sensory attributes of the various fermented beverages fermented with $L$. plantarum during refrigerated storageup to 20 days have been shown in Table 6 . The probiotic beverage based on whey and fruit juices showed no sensory differences in refrigerated storage for the first 10 days. But after 20 days, the observed difference was in flavor. Based on the consensus made by the panelists, the main characteristics of the product were acidity and sweetness and over time acidity is predominant. Acidity gradually increased and thus it was the characteristic responsible for the sensory distinction observed by the panelists especially after 20 days of cold storage. Sensory analysis showed that fermented beverages formulated with $30 \%$ cactus pear juices (C30) obtained the highest score for appearance, flavor and overall acceptability at 1 and 10 days of cold storage. However, the sensory attributes deteriorated and almost all beverages were unacceptable at final storage time (20 days) and this could be associated with the increased acidity resulted by probiotic growth and carbohydrates degradation. Generally, the current results are in line with that reported by Cakmakcı et al. (2012) where the nutritional and sensorial properties improved by fruit incorporation. Recently, Desouky (2018) showed that cactus pear fruit pulp enhanced the sensory characteristics of goat milk bio-yoghurt beverages and were more accepted by panelists, rated above average, especially when fermented with a probiotic starter culture.

TABLE 6. Sensory evaluation of whey-based fruit beverages fermented with Lactobacillus plantarum during cold storage time at $5^{\circ} \mathrm{C}$.

\begin{tabular}{|c|c|c|c|c|c|}
\hline $\begin{array}{c}\text { Storage } \\
\text { time (days) }\end{array}$ & C10 & $\mathrm{C20}$ & C30 & K10 & K20 \\
\hline \multicolumn{6}{|c|}{ Color and appearance (10) } \\
\hline 1 & $8 \pm 0.50^{\mathrm{aA}}$ & $9 \pm 0.50^{\mathrm{aA}}$ & $9 \pm 1.00^{\mathrm{aA}}$ & $9 \pm 1.00^{\mathrm{aA}}$ & $8.5 \pm 0.50^{\mathrm{aA}}$ \\
\hline 10 & $7 \pm 1.00^{\mathrm{aA}}$ & $9 \pm 1.00^{\mathrm{aA}}$ & $9 \pm 0.50^{\mathrm{aA}}$ & $9 \pm 1.00^{\mathrm{aA}}$ & $8.5 \pm 1.50^{\mathrm{aA}}$ \\
\hline 20 & $7.5 \pm 0.50^{\mathrm{aA}}$ & $8 \pm 0.50^{\mathrm{aA}}$ & $8.5 \pm 0.50^{\mathrm{aA}}$ & $8 \pm 1.00^{\mathrm{aA}}$ & $7.5 \pm 1.00^{\mathrm{aA}}$ \\
\hline \multicolumn{6}{|c|}{ Texture (30) } \\
\hline 1 & $25 \pm 2.00^{\mathrm{aA}}$ & $28 \pm 1.00^{\mathrm{aA}}$ & $29 \pm 1.00^{\mathrm{aA}}$ & $29 \pm 1.00^{\mathrm{aA}}$ & $25 \pm 0.50^{\mathrm{aA}}$ \\
\hline 10 & $24 \pm 1.5^{\mathrm{aA}}$ & $28 \pm 1.00^{\mathrm{aA}}$ & $29 \pm 0.50^{\mathrm{aA}}$ & $28 \pm 1.00^{\mathrm{aA}}$ & $24 \pm 1.00^{\mathrm{aA}}$ \\
\hline 20 & $23 \pm 1.00^{\mathrm{aA}}$ & $25 \pm 2.00^{\mathrm{aA}}$ & $26 \pm 1.00^{\mathrm{aA}}$ & $25 \pm 2.00^{\mathrm{aA}}$ & $23 \pm 2.00^{\mathrm{aA}}$ \\
\hline \multicolumn{6}{|c|}{ Flavor (60) } \\
\hline 1 & $55 \pm 2.00^{\mathrm{bA}}$ & $56 \pm 1.00^{\mathrm{bA}}$ & $59 \pm 0.50^{\mathrm{aA}}$ & $58 \pm 0.50^{\mathrm{aA}}$ & $56 \pm 1.00^{\mathrm{bA}}$ \\
\hline 10 & $55 \pm 2.00^{\mathrm{bA}}$ & $56 \pm 1.00^{\mathrm{bA}}$ & $58 \pm 1.00^{\mathrm{aA}}$ & $56 \pm 1.50^{\mathrm{aA}}$ & $55 \pm 2.00^{\mathrm{aA}}$ \\
\hline 20 & $47 \pm 3.00^{\mathrm{aB}}$ & $48 \pm 2.00^{\mathrm{aB}}$ & $47 \pm 2.50^{\mathrm{aB}}$ & $48 \pm 2.00^{\mathrm{aB}}$ & $48 \pm 4.00^{\mathrm{aB}}$ \\
\hline \multicolumn{6}{|c|}{ Overall acceptability (100) } \\
\hline 1 & $89 \pm 1.50^{\mathrm{aA}}$ & $93 \pm 2.00^{\mathrm{bA}}$ & $97 \pm 1.00^{\mathrm{aA}}$ & $96 \pm 2.00 \mathrm{aA}$ & $95.5 \pm 2.00^{\mathrm{aA}}$ \\
\hline 10 & $86 \pm 1.50^{\mathrm{bA}}$ & $91 \pm 1.00^{\mathrm{bA}}$ & $95 \pm 2.00^{\mathrm{aA}}$ & $94 \pm 1.00^{\mathrm{aA}}$ & $93 \pm 1.50^{\mathrm{aA}}$ \\
\hline 20 & $73 \pm 3.00^{\mathrm{aB}}$ & $75 \pm 2.50^{\mathrm{aB}}$ & $76 \pm 2.50^{\mathrm{aB}}$ & $75 \pm 5.00^{\mathrm{aB}}$ & $74 \pm 2.5 \mathrm{aB}$ \\
\hline
\end{tabular}

Values are means \pm SD of three independent experiments. Means with different superscripts (A, B...) in each row for each type of fruit added at the same time for the various treatments are significantly different $(\mathrm{P}<0.05)$ while means with different superscripts $(\mathrm{a}, \mathrm{b} . .$.$) in each column at various storage time for each treatment are significantly different$ $(\mathrm{P}<0.05)$. C10, C20, C30: whey-based fruit beverages fermented with $L$. plantarum containing 10, 20, $30 \%$ cactus pear juice, respectively. K10 and K20: whey-based fruit beverages fermented with L. plantarum containing 10 and $20 \%$ kaki juice, respectively. 


\section{Conclusion}

It can be concluded that sweet whey could be useful in the formulation of several beverages especially that fermented with probiotic bacteria. In addition, cactus pear and kaki fruit juices, as valuable food containing several nutrients and bioactive components, could be exploited in preparation of fermented probiotic beverages of high quality. Fruit juices incorporation increased the nutritional value and antioxidant activity of the resultant beverages. Moreover, it is useful in improving the viability of $L$. plantarum and increasing the total phenolic content and antioxidant activity. Thus, the resulted beverages are more valuable and have strong functionality.

\section{Conflict of interest}

The authors declare that they have no conflict of interest.

\section{References}

Aamer, R., El-Kholy, W. and Mailam, M. A. (2017). Production of functional beverages from whey and permeate containing kumquat fruit. Alexandria $J$. Food Sci. \& Tech., 14 (1), 41-56.

AbdulAlim, T. S., Zayan, A. F., \& Campelo, P. H. (2018). Development of new functional fermented product: mulberry-whey beverage. J. Nutr. Food Technol., 1 (3), 64-69.

Abirami, A., Nagarani, G. and Siddhuraju, P. (2014). In vitro antioxidant, antidiabetic, cholinesterase and tyrosinase inhibitory potential of fresh juice from Citrus hystrix and C. maxima fruits. Food Sci. Hum. Wellness, 3, 16-25.

Akpinar, A., Torunoğlu, A., Yerlikaya, O., Kınık, Ö., Akbulut, N., \& Uysal, H. (2015) Fermented probiotic beverages produced with reconstituted whey and cow milk:Sensorial and rheological properties. Agro. Food Industry Hi. Tech., 26 (4), 24-27.

Albano, C., Negro, C., Tommasi, N., Gerardi, C., Mita, G., Miceli, A. and Blando, F. (2015) Betalains, phenols and antioxidant capacity in cactus pear [Opuntia ficus-indica (L.) Mill.] fruits from Apulia (South Italy) genotypes. Antioxidants, 4 (2), 269280.

Almeida, K.E., Tamime, A.Y. and Oliveira, M.N. (2008) Acidification rates of probiotic bacteria in Minas frescal sheese whey. LWT Food Sci.Tech. 41, 311-316.
AOAC (2007) Association of Official Analytical Chemists. Official Method of Analysis ( $18^{\text {th }} \mathrm{ed}$.), pp. 302-850. Benjamin Franklin Station Washington, D.C., USA.

Arba, M.(2006) Dellahia a cactus pear cultivar from the Mediterranean coast of northern Morocco. Acta Horticult. 728, 37-41.

Baccouche, A., Ennouri, M., Felfoul, I. and Attia, H. (2013) A physical stability study of whey-based prickly pear beverages. Food Hydrocolloids, 33, 234-44.

Bhavsagar, M. S., Awaz, H. B. and Patange, U. L. (2010) Manufacture of pineapple flavoured beverage from chhana whey. J. Dairying Foods \& Home Sci. 29 (2), 110-113

Božanić, R., Barukčić, I. and Lisak, K. (2014). Possibilities of whey utilisation. Austin J. Nutr. Food Sci., 2 (7), 1036.

Brand-Williams, W., Cuvelier, M. E. and Berset, C. (1995) Use of a free radical method to evaluate antioxidant activity. LWT Food Sci. Technol. 28, 25-30.

Bulatović, M. L., Krunić, T. Z., Vukasinović-Sekulić, M. S., Zarić, D. B. and Rakin, M. B. (2014) Quality attributes of a fermented whey-based beverage enriched with milkand a probiotic strain. $R S C A d v$., 4, 55503-55510.

Cakmakcı, S., Cetin, B., Turgut, T., Gurses, M. and Erdoğan, A. (2012) Probiotic properties, sensory qualities, and storage stability of probiotic banana yogurts. Turk. J. Vet. Anim. Sci. 36, 231-237.

Capela, P., Hay, T.K.C. and Shah, N.P. (2006). Effect of cryoprotectants, prebiotics and microencapsulation on survival of probiotic organisms in yoghurt and freeze-dried yoghurt. Fd Res. Int., 39, 203-211.

Castro, W. F., Cruz, A. G., Rodrigues, D., Ghiselli, G., Oliveria, C. A. F., Faria, J. A. F., Godoy, H. T. (2013) Effects of different whey concentrations on physicochemicalcharacteristics and viable counts of starter bacteria in dairy beverage supplemented with probiotics. J. Dairy Sci., 96, 96-100.

Chavan, R. S., Shraddha, R. C., Kumar, A. and Nalawade, T. (2015) Whey based beverage: its functionality, formulations, health benefits and applications. J. Food Processing \& Tech., 6 (10), $1-8$. 
Dalvi, L. T., Moreira, D. C., Alonso, A., de Avellar, I. G., and Hermes-Lima, M. (2018) Antioxidant activity and mechanism of commercial Rama Forte persimmon fruits (Diospyros kaki). Peer J., 6, 5223, 1-22.

Darwish, A. A., El-Deeb, Amany, M. and Elgindy, A. A. E. (2018) Viability of probiotic bacteria in fermented milk beverages containing roasted date palm kernel. Middle East J. Appl. Sci. 8 (4), 1273-1289.

Desouky, M. M. (2018) Effect of using cactus pear pulp on the properties of goats' milk bio- yoghurt drinks. Egypt. J. Food Sci., 46, 25 - 41.

Dilmi-Bouras, A. (2006) Assimilation (in vitro) of cholesterol by yoghurt bacteria. Ann. Agric. Environ. Med., 13 (1), 49-53.

Enigbokan, M., Felder, T.B., Thompson, J.O, Kuti, J.O. and Ekpenyong, K.I. (1996). Hypoglycemic effects of Opuntia ficus indica Mill. Opuntia lindheimeri Engelem and Opuntia robusta Wendel in streptozotocin-induced diabetic rats. Phytotherapy Res., 10, 379-382.

Espirito-Santo, A. P., Lagazzo, A., Sousa, A. L. O. P., Perego, P., Converti, A. and Oliveira, M. N. (2013) Rheology, spontaneous whey separation, microstructure and sensorial characteristics of probiotic yoghurts enriched with passion fruit fiber. Food Res. Int., 50, 224-231.

FAO, (2013). Agro-industrial utilization of cactus pear. Rome. Rural Infrastructure and Agro-Industries Division, in collaboration with the International Technical Cooperation Network on Cactus (FAOCACTUSNET), $168 \mathrm{p}$.

Farahat, A. M. and El-Batawy, O. (2013). Proteolytic activity and some properties of stirred fruit yoghurt made using some fruits containing proteolytic enzymes. World J. Dairy and Food Sci., 8 (1), 38-44.

Feugang, J.M., Konarski, P., Zou, D., Stintzing, F.C. and Zou, C. (2006) Nutritional and medicinal use of cactus pear (Opuntia spp.) cladodes and fruits. Frontiers in Bioscience, 11, 2574-2589.

Forman, H.J., Davies, K.J.A. and Ursini, F. (2014) How do nutritional antioxidants really work: nucleophilic tone and para-hormesis versus free radical scavenging in vivo. Free Radical Biology \& Medicine, 66, 24-35.

Gad, A. S., Emam, W. H., Mohamed, G. F. and Sayd, A. F. (2013) Utilization whey in production of functional healthy beverage "whey-mango beverages”. Am. J. Food Tech., 8 (3), 133-148.

Egypt. J. Food. 47, No.2 (2019)
Guzman-Gonzalez, M., Morais, F., Ramos, M. and Amigo, L. (1999) Influence of skimmed milk concentrate replacement by dry dairy products in a low-fat set-type yoghurt model system. I: Use of whey protein concentrates, milk protein concentrates and skimmed milk powder. J. Sci. Food Agr., 79 (8), 1117-1122.

Ha, E. and Zemel, M. B. (2003). Functional properties of whey, whey components, and essential amino acids: mechanisms underlying health benefits for active people. J. Nutr. Biochem., 14: 251-258.

Jeličić, I., Božanić, R. and Tratnik, L. (2008) Whey based beverages-new generation of dairy products. Mljekarstvo, 58 (3), 257-274.

Keating, K.R. and White, C.H. (1990). Effect of alternative sweeteners in plain and fruit-flavored yogurts. J. Dairy Sci., 73, 54-62.

Lee, H.C., Jenner, A.M., Low, C.S. and Lee, Y.K. (2006) Effect of tea phenolics and their aromatic fecal bacterial metabolites on intestinal microbiota. Res. Microbiol. 157, 876-888.

Lee, J. H., Lee, Y. B., Seo, W. D., Kang, S. T., Lim, J. W. and Cho, K. M. (2012). Comparative studies of antioxidant activities and nutritional constituents of persimmon juice (Diospyros kaki L. cv. Gapjubaekmok). Preventive Nutrition and Food Science, 17 (2), 141.

Luo, z. and Wang, R. (2008). Persimmon in China: Domestication and traditional utilization of genetic resources. Adv. Hort. Sci., 22, 239.

Magloire, J.F., Konarski, P., Zou, D., Stintzing, F.C. and Zou, C. (2006) Nutritional and medicinal uses of cactus pear (Opuntia sp.) cladodes and fruits. Front. Biosci. 11, 2574-2589.

Mahmood, A., Abbas, N. and Gilani, A. H. (2008) Quality of stirred buffalo milk yogurt blended with apple and banana fruits. Pak. J. Agric. Sci, 45 (2), 275-279.

Mantzourani, I., Kazakos, S., Terpou, A., Alexopoulos, A., Bezirtzoglou, E., Bekatorou, A. and Plessas, S. (2019) Potential of the Probiotic Lactobacillus Plantarum ATCC 14917 Strain to Produce Functional Fermented Pomegranate Juice. Foods, 8 (1), 4, 1-13

Maulidiani, M., Mediani, A., Abas, F., Park, Y.S, Park, Y.K., Kim, Y.M. andGorinstein, S. (2018) $1 \mathrm{H}$ NMR and antioxidant profiles of polar and non-polar extracts of persimmon (Diospyros kaki L.)-metabolomics study based on cultivars and origins. Talanta, 184, 277-286. 
Muñoz, d.e., Chávez, M., Chávez, A., Valles, V. andRoldán, J.A. (1995) The nopal: a plant of manifold qualities. World Rev. Nutr. Diet., 77, 109134.

Nairu, B., Ingole, A. S., Patil, S. R., Swati, B. and Surekha, M. (2011) Effect of orange pulp extract on sensory quality, chemical properties and cost structure of chakka whey beverage. J. Soils Crops, 21 (2), 318-323.

Nazir, A., Wani, S. M., Gani, A., Masoodi, F. A., Haq, E., Mir, S. A.,and Riyaz, U. (2013) Nutritional, antioxidant and antiproliferative properties of persimmon (Diospyros kaki) -a minor fruit of J\&K India Int. J. of Adv. Res., 1 (7), 545-554.

Park, Y.S., Leontowicz, H., Leontowicz, M., Namiesnik, J., Jesion, I. and Gorinstein, S. (2008). Nutraceutical value of persimmon (Diospyros kaki Thunb.) and its influence on some indices of atherosclerosis in an experiment on rats fed cholesterol-containing diet. Adv. Hort. Sci., 22, 250-254.

Prashanth, B. M., Jayaprakash, H. M., Soumyashree, T. C. and Madhusudhan, N. M. (2018). Development of fruit enriched whey beverage. Int. J. Chem. Stud., 6 (2), 2386-2392.

Ragab, W. A., El-Moshtohry, E. A. E. and Hussein, F. M. (2010) Chemical, microbiological and organoleptic characteristics of whey beverages manufactured using guava and probiotic bacteria. J. Home Econ. 20 (3), 1-13.

Sáenz, C., Sepúlveda, E. and Matsuhiro, B. (2004). Opuntia spp. Mucilage: a functional component with industrial perspectives. J. Arid Environ. 57 (3), 275-290.

Sáenz, C., Berger, H., Rodríguez-Félix, A., Galleti, L., Corrales García, J. and Sepúlveda, E. (2013) Agro-industrial utilization of cactus pear. Food and Agriculture Organization, Rome. Available at http://www.fao.org/3/a0534e/a0534e.pdf.

Smithers, G. W., Ballard, F. J., Copeland, A. D., Desilva,
K., Dionysius, D. A., Francis, G. L., Guddard, E., Griene, P. A. and Digester, G. O. (1996). New opportunities from the isolation and utilization of whey proteins. J. Dairy Sci., 79 (6), 1454-1459.

Sreerupa, S., Sangeeta, S., Chandan, R. and Sauryya, B. (2014). Effect of storage and preservatives on antioxidant status of some refrigerated fruit juices. International Journal of Current Microbiology and Applied Science, 3, 1007-1013.

Stintzing, F.C., Schieber, A. and Carle, R.C. (2003). Evaluation of colour properties and chemical quality parameters of cactus juices. Eur. Food Res. \& Tech. 216, 303-311.

Suzuki, T., Someya, S.H.F. and Tanokura, M. (2005). Comparative study of catechin compositions in five Japanese persimmons (Diospyros kaki). Food Chem., 93, 149.

Turkmen, N., Akal, C., \& Özer, B. (2019). Probiotic dairy-based beverages: A review. J. Funct. Foods, 53, 62-75.

Vandenplas, Y., Huys, G. and Daube, G. (2015) Probiotics: An update. J. Pediatr., 91, 6-21.

Vercet, A., Oria, R.., Marquina, P., Crelier, S., and Lopez-Buesa,P. (2002) Rheological properties of yoghurt made with milk submitted to manothermosonication. J. Agric. Food Chem., 50, 6165-6171.

Yang, X., Zhou, J., Fan, L., Qin, Z., Chen, Q. and Zhao, L. (2018) Antioxidant properties of a vegetablefruit beverage fermented with two Lactobacillus plantarum strains. Food sci. \& Biotech., 27 (6) 1719-1726.

Yaqub, S., Farooq, U., Shafi, A., Akram, K., Murtaza, M. A., Kausar, T. and Siddique, F. (2016) Chemistry and functionality of bioactive compounds present in persimmon. J. Chem., 1-13.

Yonis, A. A. M., Nagib, R. M. and Abo Nishouk, L. A. (2014) Utilization sweet whey in production of whey guava beverages. J. Food and Dairy Sci., Mansoura Univ., 5 (10), 731 - 739, 


\title{
صفات الجودة لمشروبات الفاكهة المصنعة من الثرش الحلو والمتخمرة ببكتريا Lactobacillus plantarum
}

عصمت على ، علياء درويش و ميراندا توفيق

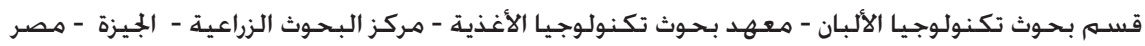

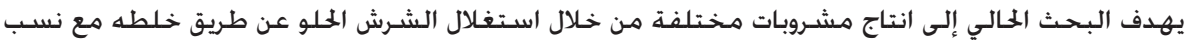

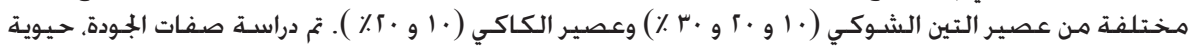

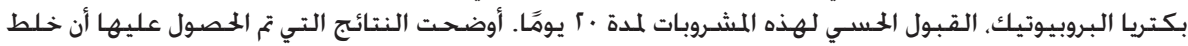

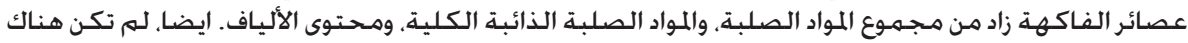

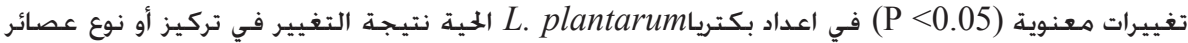

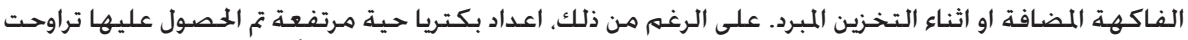

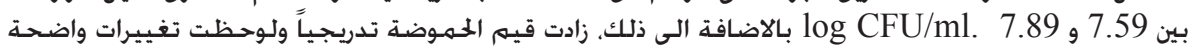

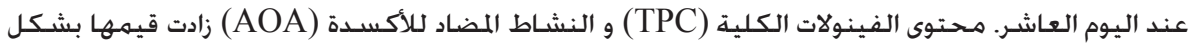

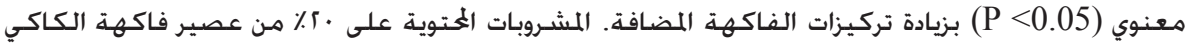

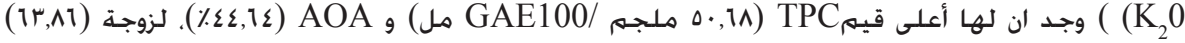

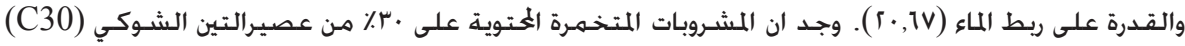

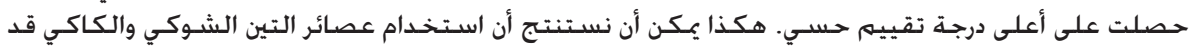

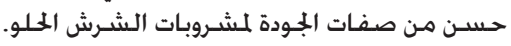

